TITLE:

\title{
Long-term expansion of alveolar stem cells derived from human iPS cells in organoids(Abstract_要旨)
}

\author{
AUTHOR(S): \\ Yamamoto, Yuki
}

\section{CITATION:}

Yamamoto, Yuki. Long-term expansion of alveolar stem cells derived from human iPS cells in organoids. 京都大学, 2018, 博士(医学)

ISSUE DATE:

2018-03-26

URL:

https://doi.org/10.14989/doctor.k21007

RIGHT:

学位規則第9条第2項により要約公開 


\begin{tabular}{|c|l|c|c|}
\hline 京都大学 & 博士 $\quad$ 医 学) & 氏 名 & \multicolumn{1}{|c|}{ 山本 佑樹 } \\
\hline 論文題目 & $\begin{array}{l}\text { Long-term expansion of alveolar stem cells derived from human iPS cells in } \\
\text { organoids } \\
\text { (オルガノイド形成下におけるヒトiPS 細胞由来肺胞幹細胞の長期培養 })\end{array}$ \\
\hline
\end{tabular}

（論文内容の要旨）

II 型肺胞上皮細胞は肺胞領域における組織幹細胞とされ、自己複製能と I 型肺胞上 皮細胞一の分化能をもつとともに、サーファクタントを分泌して肺の虚脱を防ぐ。難 治性呼吸器疾患の病態形成において、II型肺胞上皮細胞の異常との関連が示唆されて おり、創薬標的としての関心も高い。しかし研究用に得られるヒトII型肺胞上皮細胞 は非常に限られており、また培養維持もできず、病態解明や創薬への応用は困難で女 った。ヒト iPS 細胞はII型肺胞上皮細胞の有力な細胞ソースになり得ると考えられ、 分化誘導方法の研究が行われてきたが、分化効率が不十分なものが多く、長期培養の 報告もなかった。

まず、ヒト iPS 細胞から発生期肺の初期マーカーである NKX2-1+腹側前方前腸細胞 を分化誘導した。この細胞をCHIR99021，FGF10，KGF，DAPT を含む培地で 7 日間培養 (前処理) してからヒト胎児肺線維芽細胞と共培養したところ約 50\%の効率で而型 肺胞上皮細胞の分化マーカーSFTPC の陽性細胞を含む肺胞オルガノイドが形成され た。肺胞オルガノイドにはラメラ体と呼ばれる II 型肺胞上皮細胞に特徵的な細胞小器 官をもつ細胞が観察され、 $\mathrm{SFTPC}^{+}$細胞における網羅的遺伝子発現解析では II 型肺胞上 皮細胞に特徴的な遺伝子群の発現上昇が確認された。“前処理”による前駆細胞の変 化と II 型肺胞上皮細胞の分化との関連を調べるため、シングルセル RNA シークエンシ ングを用いて分化誘導過程における遺伝子発現の変化を解析すると、“前処理”によ って前駆細胞はより II 型肺胞上皮細胞に近い遺伝子発現パターンに移行寸ることが 示された。細胞分化状態の変化を特徵づける遺伝子群には肺胞発生に重要とされる転 写因子が含まれていた。さらに、線維芽細胞との共培養なしで肺胞オルガノイドを作 成する方法も検討し、CHIR99021 と SB431542 を添加した培地で前駆細胞を三次元培 養することで、SFTPC+細胞を約 $20 \%$ の効率で分化誘導できた。

次に iPS 細胞由来 $\mathrm{SFTPC}^{+}$細胞を単離し、胎児肺線維芽細胞との共培養下で才ルガ ノイド形成を繰り返し継代すると、3 ケ月以上に渡って長期培養することが出来た。 継代を続けた肺胞オルガノイドには SFTPC ${ }^{+}$細胞が維持される一方、I 型肺胞上皮様 細胞への分化も確認された。iPS 細胞由来 $\mathrm{SFTPC}^{+}$細胞のトランスクリプトームを成人 II 型肺胞上皮細胞と比較すると、継代を続けても II 型肺胞上皮細胞に比較的近い遺伝 子発現パターンが維持されていた。

分化誘導後長期継代した iPS 細胞由来 $\mathrm{SFTPC}^{+}$細胞を電子顕微鏡で観察すると幼若 な II 型肺胞上皮細胞が含まれ、不均一な細胞集団であると考えられたので、1 細胞レ ベルで遺伝子解析すると、I 型肺胞上皮細胞マーカーの共発現の程度により 3 群に分 類された。マウスの肺発生期のデータとの対比により、iPS 細胞由来 $\mathrm{SFTPC}^{+}$細胞には マウスで終末囊胞期に出現し I 型・II型双方の肺胞上皮細胞への分化能を持つ両能性 細胞に対応する細胞群が含まれている可能性が示唆された。

最後に、肺胞オルガノイドを薬剤毒性試験に応用した。II型肺胞上皮細胞のラ メラ体に形態異常を来すことが知られている 2 種類の薬剤を肺胞オルガノイドに
曝露させたところ、生体内で報告されているのと同様の現象が再現され、網羅的遺伝子発 現解析で違いを調べることができた。本研究により iPS 細胞由来肺胞幹細胞の効率的な分 化誘導法と長期培養法が開発され、薬剤毒性試験への応用も示された。今後、肺実質障害 を伴う呼吸器疾患モデリングを通じた創薬や再生医療に役立つ可能性があると考えられ る。

\section{(論文審査の結果の要旨)}

II 型肺胞上皮（AT2）細胞は肺胞領域の組織幹細胞であり、その異常は種々の難治性呼吸器疾患 の病態形成に関連し、その分化誘導方法の確立は、疾患の病態解析や創薬研究を飛躍させる。申請 者は、ヒト iPS 細胞から AT2 細胞への分化効率を高め、長期培養増殖法を開発することで、安定し た AT2 細胞ソースの確立を目指した。まず、iPS 細胞より段階的に分化誘導した NKX2-1 陽性肺前 駆細胞は、KGF, FGF, CHIR, DAPT を含む培地で 1 週間培養することにより AT2 細胞への分化効率 が上昇すること、またこれらの細胞を三次元共培養下に継代することで肺胞幹細胞性を維持したま ま長期間培養できることを示した。次に、GSK3 $\beta$ 阻害薬とTGF $\beta$ 阻害薬とを組み合わせて培養する ことにより線維芽細胞なしでAT2 細胞へ分化させる方法を開発した。さらに、iPS 細胞由来 AT2 細 胞への分化や長期培養の過程の遺伝子発現を 1 細胞レベルで解析し、分化に重要と考えられる細胞 集団が不均一であり、マウス肺発生段階の細胞不均一性を再現していた。最後に薬㶡性肺傷害モデ ルとして、2 種類の薬剤を肺胞オルガノイドに曝露させ、異なる機序の薬剤応答性を確認し、iPS 細 胞を用いた肺毒性試験への応用可能性を示した。

以上の研究は、ヒト肺胞上皮細胞の分化・維持機構の解明に貢献し、将来の難治性呼吸器疾患の 再生医療や創薬に寄与するところが大きいと期待される。

したがって、本論文は博士 (医学) の学位論文として価值あるものと認める。

なお、本学位授与申請者は、平成 30 年 2 月 20 日実施の論文内容とそれに関連した試問を受 け、合格と認められたものである。 